\title{
A Rapid Flow Of Emerging Business Technologies And Their Effects On Modern Companies Through BBM With Reference To Changing Business Patterns
}

Nadir Ali Kolachi, (E-mail: nadir.kolachi@gmail.com), Bahria University, Karachi, Pakistan Abu Zar Wajidi, (E-mail: abuzar_wajidi@ hotmail.com), Karachi University, Karachi, Pakistan

\begin{abstract}
Technologies of different shapes have got much speed from 1960 to present. In 1970, the computer technology brought lots of accelerated modes of business when the faster calculations and saving data became possible. It further innovated the big information systems after 1985 when the manual work started to be converted into computerized means as computer based information systems. But one thing brought various solutions to the business and that is the miraculous advent of Internet after 1992.

An Internet is one of the biggest emerging business technologies which has facilitated the business platform in much faster and flexible standards. Due to this technology, the business is advanced at an exponential rate of making life very easy and guiding to be equipped with other technological wonders that are not only doing business but increasing educational activities, knowledge and coordination through organization to organization and customers to customers. The purpose of this paper is to identify emerging business technologies with special focus on ecommerce and get a sneak peak into internet and information literacy related technologies which will pull e-com any time to millions of people and push business to survive on modern business methods. The study will also focus on emerging business technologies that have emerged through the last decade or so. The study will also focus on strategic approach with reference to changing business patterns by developing BBM (Better Business Model) for modern companies including the significance of the model and its role in business scenario.

The paper consists of five main sections: First is about the introduction, concept and definitions of the topic, Second is regarding the historical perspective of emerging technologies and identification of e-com emerging technologies and their changing phase in the faster pace of information technology and business aspects, Third focuses on the model of e-com and computer technology development. Fourth is followed by the conclusions, recommendations, research methodology, references and bibliography.
\end{abstract}

Keywords: Emerging technologies, business and changing business patterns

\section{INTRODUCTION}

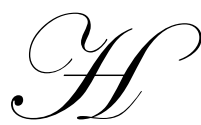

activities.

istory of technology development is long story of electronic business affair but some of the important icons which initiated and proposed the emerging technologies development in an IT age are EDI, Internet \& Web service, DSL, Ecom \& Mcom applications and many other Online

EDI has always been in the help of better business but its high cost standards are complicated and its huge complexities in the application have hindered the EDI popularity in the business. But after the advent of an internet, it is a bit popular as internet EDI activities towards business processes. The internet pushed many companies to be connected with their suppliers, customers and competitors in particular for the purpose of better business activities. 
This push compelled companies to have web existence to have an edge in miraculous innovations of information technology. XML and Web service provide a development tool for defining format of the data interchange in a wide variety of business communities where web service offer an effective architecture for the business and communication initiatives. An XML and Web services are shaping in very effective manners to all ecom technologies. Lots of new things have also been evolved in this regard. On the other hand, DSL brought an exponential growth in the world of e-com due to its twenty four hours communication across the world. This provides digital communication on copper wire of the local telephone network and got much popularity after the faster pace of electronic business scenario. All such services and applications opened a very wide space for Ecom \& Mcom activities. The development in mobile and portable gadgets created very easy and flexible platform for companies to provide all commercial activities at their time. Mobile commerce is an extension concept of e-com which provides all same facilities in mobile means. This concept was the result of the boom in dot com companies which brought lots of communication on the applications via broad band mobile telephony and other technologies. Based on the above factors an online scenario progressed at the rapid pace. In this process, an online ticketing, online banking, online selling and all the results of advancement in networked devices and web services became common phenomena. The banking sector is much benefited by e-com concepts, the same is the case with trading, companies having an online trades etc. The ATMs facility of banking sector is one of the emerging technologies which is being adopted by almost every body.

Technology has always been a great influence on the business patterns because of its innovation and advancement in inventions. There are lots of technological icons which are responsible to modify the methodology of business trends but computer related technologies are the major controlling icons on the world's business desktop. Following technologies are considered as important factors.

\begin{tabular}{|c|c|c|}
\hline $\begin{array}{c}\text { Computer Technology } \\
\text { (Software based) }\end{array}$ & $\begin{array}{c}\text { Computer Technology } \\
\text { (Hardware based) }\end{array}$ & Business related Technology \\
\hline $\begin{array}{ll}\text { - } & \text { Information Technology } \\
- & \text { Information Systems } \\
- & \text { Information Superhighways } \\
\text { - } & \text { Information Literacy } \\
\text { - } & \text { Information Layers }\end{array}$ & $\begin{array}{ll}\text { - } & \text { IT Systems } \\
\text { - } & \text { Machines } \\
\text { - } & \text { Man-Machine Interface } \\
\text { - } & \text { Commork Gadgets } \\
\end{array}$ & $\begin{array}{ll}\text { - } & \text { Electronic Commerce } \\
\text { - } & \text { Electronic Business } \\
\text { - } & \text { Electronic Marketing } \\
\text { - } & \text { CRM } \\
\text { - } & \text { ERPs \& SCMs }\end{array}$ \\
\hline
\end{tabular}

The changing business patterns are the results of customers' knowledge and preferences. The customers who are information literate and have an access to modern communication methods can check the competitor's products and order them to get products with in no time. Such thing pushes the organization to change the outdated business styles but adopt the one which is most compatible with the needs of the country and customers around the world. The major changes occurred when technological development started after 1970 with the introduction of microprocessor chip which brought lots of capacity of maintaining and preserving customers' data, faster calculation and accurate methods. The other change appeared when the information systems got much popularity of changing manual information systems towards computer based information systems. The third one which brought lots of other changes and turned the world into one village was the miraculous advent of internet. This technology facilitated the business organization to have web existence and ubiquitous scenario. This gave birth and flourished other wonderful emerging concepts of emerging technologies like electronic Business, electronic commerce, and mobile business and commerce.

Such flexible and worldly available facility convinced many organizations to work for eruptive and disruptive concept of technologies and started to produce not only one product line but to come up with multiple product line offerings. For example, companies who were doing internet facilities came up with software, information system packages, providing compatible machines etc. In this way all companies dived into the domain of designing strategic packages and acceptable product differentiations having an hawk's eye on the competitors strategies and predictive plans. Such competition brought a very good flow of choices for the customers and the power which was with the sellers shifted to buyers because of the countless choices in every domain of items. 
Despite of tremendous accomplishments of internet and communication technologies, it has also been observed that world's major business activities depend on full integration of the globe. Customers know the product but want to reach it with in no time. In this way, companies look for such kind of solution that can satiate the need of the customers immediately, that's why companies joined the party of major business trends which include greater pervasiveness of computers continuing convergence of computing and communication, greater automation of work, faster pace of business, accelerating global competitiveness and gradual acceptance of global standards.

Following is the model which explains the trend of technology from 1960 to present indicating the changing business patterns due to the advancement in computers, information technology and e-commerce that has created a base for emerging definite technologies named as emerging business technologies.

\begin{tabular}{|l|l|l|l|}
\hline \multicolumn{1}{|c|}{ Technology } & \multicolumn{1}{|c|}{ Years } & Emerging Technologies & \multicolumn{1}{c|}{ Business Patterns } \\
\hline $\begin{array}{l}\text { MRP } \\
\text { MRP-II }\end{array}$ & $1960 \mathrm{~s}$ & EDI & Coordination, Simple processes in HRM and Engineering \\
\hline $\begin{array}{l}\text { Computers } \\
\text { Microchip }\end{array}$ & $1970 \mathrm{~s}$ & $\begin{array}{l}\text { EDI, Terminals and } \\
\text { Computers }\end{array}$ & Faster processes, Faster calculation, Methodology improved \\
\hline $\begin{array}{l}\text { Information } \\
\text { Systems }\end{array}$ & $1980 \mathrm{~s}$ & $\begin{array}{l}\text { Information } \\
\text { Systems, MIS, } \\
\text { CBIS, ESS, and DSS }\end{array}$ & $\begin{array}{l}\text { Manual Information, Coordination and other business activities, } \\
\text { communication flow from first line to middle and top level } \\
\text { managers }\end{array}$ \\
\hline $\begin{array}{l}\text { Internet } \\
\text { Electronic } \\
\text { Commerce }\end{array}$ & $1990 \mathrm{~s}$ & $\begin{array}{l}\text { Internet, TCP/IP, } \\
\text { WEB services, } \\
\text { DSL, Gateways } \\
\text { SSL and SET }\end{array}$ & $\begin{array}{l}\text { Modern information Systems (ERPs), } \\
\text { Global village, World connectivity, World coordination, Online } \\
\text { business, CRM and SCM. }\end{array}$ \\
\hline $\begin{array}{l}\text { Mobile } \\
\text { Commerce }\end{array}$ & $\begin{array}{l}2000 \text { to } \\
\text { present }\end{array}$ & $\begin{array}{l}\text { Wireless, WAP Mobile } \\
\text { technologies } \\
\text { Micro browsers }\end{array}$ & $\begin{array}{l}\text { Mobile business } \\
\text { All activities of e-com into the mobile means }\end{array}$ \\
\hline $\begin{array}{l}\text { Eye } \\
\text { Blinking } \\
\text { Business }\end{array}$ & Future & $\begin{array}{l}\text { Eye rays } \\
\text { Eye as an infrared }\end{array}$ & $\begin{array}{l}\text { The time will come when a man will blink and the transaction } \\
\text { will happen. }\end{array}$ \\
\hline
\end{tabular}

The model explains the historical background of technology identifying the pace by emerging technologies which pushes to flat the business patterns in different organizations and countries. In 1960, when the MRP (Material Requirement Planning) was being used for the purpose of coordination at smaller level in the organization and the usage of EDI was possible at that time but at a lesser scale. After a while, it got much advancement in coordination patterns and expanded from coordination towards faster process and faster communication. The 1970s is the most memorable time because of the introduction of micro chip which exploded the world of computer technology and provided us with the faster pace, faster calculation devices and methodology of other fields was improved at satisfactory level. In this time, the EDI was also in use.

The year 1980s is the time of information systems that got much popularity when the manual information systems were converted into computer based information systems and many middle managers started using MIS, DSS and some ESS to know the complexities of maintaining data and communicating to top level hierarchy for structured and unstructured decision- making. The year 1992 is the most historical one because of the miraculous and God gifted innovation of Internet which brought all human being together all over the world and people started sharing data, retrieving information and knowing what is being done in other countries of the world. This brought lots of concepts of information superhighway and technology which also facilitated the platform for electronic business using TCP/IP for simple communication and SSL \& SET protocols for secure business transactions. This got world connectivity, communication, better relationship and reaching customers with in seconds.

The era of 2000 and onward is the era of mobile connectivity, all which is possible by e-com and is converted into mobile means because of the advancement in universal mobile communication technologies. Every time, whenever we got across with the technology innovation, we come across to know that an other small form of computer has arrived in the market and all software can be merged in it and facilitate us with almost all things which 
are possible through desktop, laptop and palmtop computers. The future is the talk of innovating smaller sizes and shapes of computers which may contain everything as communication, business transactions and sharing heavy data in particular. The futuristic amazing and interesting thing will be that small shape of technology or computers which may easily accommodate in our eye, so it will be as Eye Blinking Business where humans will look to do a transaction, they will just be required to blink and the moment they will blink, the transaction will take place. We can imagine anything and that can happen. Thanks to the inventors, developers, technologists, teachers and researchers for bringing every time some thing very amazing.

Developing BBM (Better Business Model) for identifying customers, competitors and the demanded trend of business, this can help managers in formulating the required strategies for getting business success. Following is the model which explains some techniques to become competitive in today's market space world. The model explains the business success by the theme "If you want to be better for customers, then you have to be better than competitors"

BBM (Better Business Model)

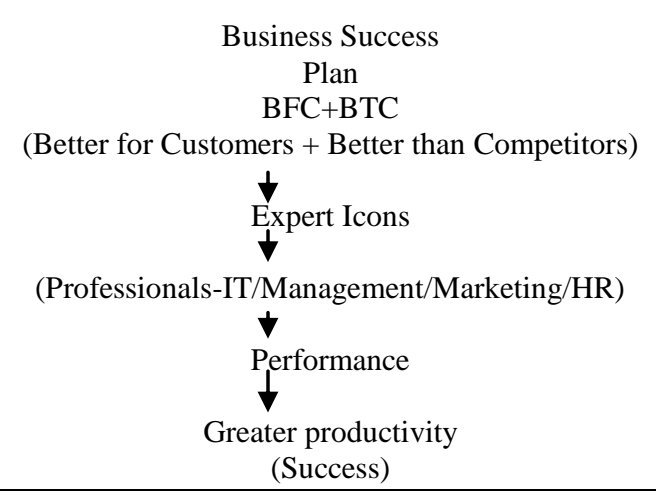

The environment has become competitive because of the faster pace in becoming the number one to adopt e-culture for the purpose of achieving business excellence. This business excellence can be achieved through some smarter strategies which are the main push to move companies towards the right competitive direction. All strategies are formulated just to keep the customers most comfortable and getting his/her conviction. Now the race is to be better in BFC (Better for Customers) which becomes possible only in joining the faster paced technology trends.

By applying lots of ecom models (brokerage, advertising and community etc) management models (porter's models, diamond and BCG matrix and many others), you can evaluate the standing but can even better for customers when you try to be BTC (Better than Competitors). Referring to the 3 Cs mentioned in ecom book (Efrain Turban-page number 73), customers, competitors and change, the last one change is the one which compels companies to be like competitors and gradually be better than them. This approach will bring lots of amelioration in company's environment and expected to have more trust of present and prospective customers. The above model is the concept of BFC+BTC which explains the business success based on better business model for attracting customers. If any company wants to get success, they need to plan. The plan is actually the BBM which is the combination of customers and competitive focus. All successful companies utilized lots of management models but BBM is the model which apprises the modern executives to be more cautious in today's competitive era. BBM is one of the step to know customers by knowing the competitors.

The term BFC (Better for Customers) is one of the requirements to be successful but BTC (Better than Competitors) is the prime requisite to be the leading organization. For maintaining the BFC+BTC, we depend on the high profile and knowledgeable professionals in the areas of IT, Management, Marketing and HR. The professionals, after focusing on BBM can work in today's faster changing environment, may it be IT, E-Business, EMkg or E-HRM. BBM is one of the plans which keep expert icons very cautious and innovative. By focusing on 
BBM, the expert people can perform very effectively which will result in greater productivity. Being better than the competitors, having good marketing strategies with required technology is a smarter step to increase the value of your company for example: Market penetration, Market and technology awareness, Dealing customers in more customized way, Knowing what your competitors are offering, you offer more than them to entice people to you.

The organization can be better when better equipped with ecom technology. When the company focuses on competitors, then they can build up strategies which can prevent their competitors from being the market leader. Such focus will give you an edge and help you to take perpetual lead in serving the needs of the customers exclusively.

\section{RESEARCH METHODOLOGY}

The research is an exploratory in nature which is based on literature survey, observation and some unstructured interviews to explore the nature and development of emerging business technologies in the developed and networked e-arena. Since the literature on e-com emerging technologies is not much available, therefore Electronic communication, Electronic business, Computer technologies and their developments \& strategic methods are mostly studied to reach and find the proper data of the topic.

\section{CONCLUSION}

Emerging Business Technologies are always at the pace of development because of the compatible development in other computer and IT related technologies. But emerging business technologies will always be on the top because of the major pertinence of business activities. Such technologies are always a very interesting topic for IT specialists to innovate and adopt for the betterment of business. In this way the technology adoption of prevailing trends and needs have become an essential part of today's top notch gurus of the organizations. The BBM is created just to inform and guide modern managers to beat the competition. If the model is focused and properly followed, then companies will not only get success but also stand as a giant competitor for others.

\section{RECOMMENDATIONS FOR PROSPECTIVE COMPANIES}

- $\quad$ Companies must be fluent with the flexible and worth adopting emerging technologies in order to achieve an edge in various issues.

- $\quad$ Companies must adopt the changing patterns of emerging technologies with the faster flow of technological advancements in the areas of networking devices and databases in particular.

- $\quad$ Companies must cope up with an IT strategy of updating some major information layered processes which are very much pertinent with modern business and strategic analysis of technology decisions by focusing on BBM model.

- $\quad$ Companies are required to watch changing business patterns through the study of consumer preferences and their trend towards technology regarding e-com and $\mathrm{m}$-com positions

- Organizations of today's age are also required to have IT experts having enough knowledge of current IT systems as to avoid from any delay to the adoption of emerging business technologies. 


\section{REFERENCES}

1. Alam, lla M.S (2001) A non parametric approach for assessing productivity dynamics of Large US banks, Journal of Money; Credit and Banking Vol 33, pp 120-139

2. Arkirava , N.K (2000) Rising productivity of Australian trading banks under deregulation 1986-1995, Journal of Economics and Finance. Vol 24.pp 122

3. Chen, T.Y \& Yeh T. (1997), A study of Efficiency evaluation in Taiwan's bank, International journal of Service Management Vol, 9, No: 5, pp 402

4. $\quad$ Electronic Commerce, A Managerial perspective by: E. Turban (Page 73)

5. $\quad$ Electronic News No: 30-July 1997

6. Worthington A. (2000) "Technology Efficiency and Technological Change in, ABACUS Vol 36, No: 2, pp 180 .

\section{Acronyms:}

ERP

CRM

SCM

EDI

MCOM

MRP

MRP II

DSL

CBIS
Enterprise Resource Planning

Customer Relationship Management

Supply Chain Management

Electronic Data Interchange

Mobile Commerce

Material Requirement Planning

Material Resource Planning II

Digital Subscriber Line

Computer Based Information Systems 